\title{
Well-being of medical students and their awareness on substance misuse: a cross-sectional survey in Pakistan
}

\author{
Abdul Wahab Yousafzai*, Syed Ahmer, Ehsanullah Syed, Naila Bhutto, \\ Saman Iqbal, Mohammed Naim Siddiqi and Mohammed Zaman
}

Address: Department of Psychiatry, Aga Khan University, Karachi 74800, Pakistan

Email: Abdul Wahab Yousafzai* - wahab.yousafzai@aku.edu; Syed Ahmer - syed.ahmer@aku.edu; Ehsanullah Syed - ehsan.syed@aku.edu; Naila Bhutto - naila.bhutto@aku.edu; Saman Iqbal - aman.iqbal@aku.edu; Mohammed Naim Siddiqi - naim.siddiqi@aku.edu; Mohammed Zaman - mohammed.zaman@aku.edu

* Corresponding author

Published: 19 February 2009

Annals of General Psychiatry 2009, 8:8 doi:10.1186/1744-859X-8-8

Received: 30 September 2008

This article is available from: http://www.annals-general-psychiatry.com/content/8/I/8

(c) 2009 Yousafzai et al; licensee BioMed Central Ltd.

This is an Open Access article distributed under the terms of the Creative Commons Attribution License (http://creativecommons.org/licenses/by/2.0), which permits unrestricted use, distribution, and reproduction in any medium, provided the original work is properly cited.

\begin{abstract}
Objective: To investigate psychological well-being and substance abuse among medical students in Pakistan.
\end{abstract}

Methods: A cross-sectional questionnaire-based survey was conducted in six medical colleges across Pakistan. Final-year medical students were interviewed by either a postgraduate trainee in psychiatry or a consultant psychiatrist.

Results: A total of 540 medical students were approached; 342 participated and the response rate was $64.5 \%$. Mean age was 23.73 years (SD 2.45 years); $52.5 \%$ were male and $90 \%$ single. Two out of every five respondents reported that work/study at medical school affected their personal health and well-being. A considerable proportion of students were aware of alcohol and smoking as coping strategies for stress in medical students. The main factors causing stress were heavy workload (47.4\%), relationship with colleagues (13.5\%) and staff (II.9\%). A total of $30 \%$ reported a history of depression and $15 \%$ among them had used an antidepressant. More than half were aware of depression in colleagues. The majority of respondents said that teaching provided on substance misuse in the areas of alcohol and illegal drugs, management/treatment of addiction, and models of addiction was poor. There was significant association $(p=0.044)$ between stress and awareness about alcohol as a coping strategy for stress among medical students. A significant negative association was also found between medical colleges in public sector $(p=0.052)$, female gender $(p=0.003)$ and well-being.

Conclusion: The majority of the medical students reported a negative impact of heavy workload on their psychological well-being. Significant numbers of medical students think that substance misuse is a coping strategy for stress. Teaching on addiction/addictive substances is poor at undergraduate level in Pakistani medical colleges. 


\section{Introduction}

Medicine has been a gratifying profession and held in high esteem since dawn of the history. It not only requires commitment, enthusiasm and altruism, but physicians are also expected to show care, compassion and a dedication to their profession.

Few studies have looked at stress related to medical education. Studies conducted in medical schools in the US and UK show a negative impact on student's physical and mental health [1-3]. A review of the literature by Liselotte et al. [4] showed the likely causes would be adjustments to the environment, ethical and moral dilemmas, exposure to human suffering, abuse, personal life events and debt. With passing years, the research highlights worsening distress and this can lead to impairment in academic performance, mental health problems and burnout.

A study from Newcastle, UK, showed that college students as a whole have a higher prevalence of alcohol drinking and alcohol use disorders than non-college youth [5]. Medical students therefore are a high-risk population. As high as $20 \%$ of first-year medical students admit to excessive alcohol intake, attributing it to stress, anxiety, and examination and work pressures [6]. A survey of eight US medical schools revealed $20 \%$ of students to have engaged in binge-drinking at least once in the past 30 days and $28 \%$ of students reported an increase in alcohol consumption during medical school [7].

Studies from Pakistan [8-10] have focused on perception of substance misuse, coping strategies and suicidal ideation among medical students. Our study looks at the wellbeing of medical students and their awareness on substance misuse, capturing data from six medical colleges across all the provinces of Pakistan.

\section{Materials and methods}

Final-year medical students were approached in six medical colleges of four provinces in Pakistan to participate in the study. These include two from North-West Frontier Province (NWFP), two in Sind Province and one each in Baluchistan and Punjab.
In total 343 students participated in the survey.

We used a questionnaire which has already been used by British Medical Association (BMA) in survey of medical student's well-being in UK [11].

The questionnaire was in the English language, which is the medium of instruction in all medical colleges in Pakistan. The questionnaire consisted of seven items with multiple responses, covering psychological well-being of the students, their awareness about substance misuse, and depression. We collapsed some of the responses for the purpose of simplicity.

A demographic extraction sheet containing age, gender, marital status and background (whether rural or urban) was used to record the demographic variables. The data was collected by either a postgraduate trainee in psychiatry or consultant psychiatrist, and the anonymity of the respondent was insured. The study was approved by departmental ethical committee.

Data was entered in SPSS version 16.0 (SPSS, Chicago, IL, USA) and the frequencies of responses calculated. We also used the chi square test to assess the significance between different variables.

\section{Results}

Out of a total of 540 medical students from the 6 medical colleges, 342 participated in the survey, yielding response rate of $64.5 \%$. The mean age of respondents was 23.73 years (standard deviation (SD) 2.45 years), 52.5\% were male and $90 \%$ were single.

With regard to ethnic distribution, $19.9 \%$ were Punjabis, 29.5\% Pukhtuns, 11.5\% Urdu speaking, 22.5\% Sindis, and $7.6 \%$ Balochi. The number of students from rural and urban backgrounds was almost equal. The overwhelming majority (91\%) were Muslims.

Tables 1 and 2 show the frequencies of responses. Three out of five respondents reported that work/study at medical school affected their personal health and well-being. Whilst $58.2 \%$ and $74.9 \%$ reported that they were not

Table I: Frequency of responses to stress-related questions

\begin{tabular}{llll}
\hline & & Responses & \\
\cline { 2 - 3 } Questions & Yes, n (\%) & No, n (\%) & Missing, n (\%) \\
\hline Has your health been affected by stress? & $234(68.6)$ & $96.1(28.1)$ & $11(3.2)$ \\
Does work at medical school affect your personal health and well-being? & $59(17.3)$ & $274(82.7)$ & 0 \\
Are you aware of use of smoking in medical students to cope with stress? & $134(39.2)$ & $199(58.2)$ & $7(2.0)$ \\
Are you aware of use of alcohol in medical students to cope with stress? & $78(22.8)$ & $256(74.9)$ & $6(1.8)$ \\
\hline
\end{tabular}


Table 2: Frequency of responses to questions related to depression

\begin{tabular}{|c|c|c|c|c|}
\hline \multirow[t]{2}{*}{ Questions } & \multicolumn{4}{|l|}{ Responses } \\
\hline & Yes, myself, n (\%) & Yes, my colleagues, $n$ (\%) & Not aware, n (\%) & Missing, n (\%) \\
\hline $\begin{array}{l}\text { Are you aware of depression amongst medical } \\
\text { students? }\end{array}$ & $103(30.1)$ & $178(52.0)$ & $52(15.2)$ & $9(2.6)$ \\
\hline $\begin{array}{l}\text { Are you aware of use of antidepressants amongst } \\
\text { medical students? }\end{array}$ & $54(15.8)$ & $180(52.6)$ & $97(28.4)$ & II (3.2) \\
\hline
\end{tabular}

aware of smoking and alcohol use as a coping strategy for stress among medical students.

Heavy workload (47.4\%), followed by relationship with colleagues $(13.5 \%)$ and staff $(11.9 \%)$ appeared to be the main sources of stress as shown in figure 1 .

While $30 \%$ of respondents reported that they have suffered from depression, only 15\% have used antidepressant medications. More than half were aware of their colleagues suffering from depression and were using antidepressant medication.

The majority of the respondents were of the opinion teaching provided on substance misuse in the areas of alcohol, illegal drugs, management/treatment of addiction, and models of addiction is poor as shown in table 3 .

The association between demographic variables and wellbeing is shown in Table 4. Government medical colleges $(\mathrm{p}$ value $=0.072)$, and female gender $(\mathrm{p}$ value $=0.003)$ had a significant association with stress. Alcohol use as coping strategy was found to be significantly associated with stress among medical students ( $\mathrm{p}$ value $=0.044$ ), as shown in Table 5.

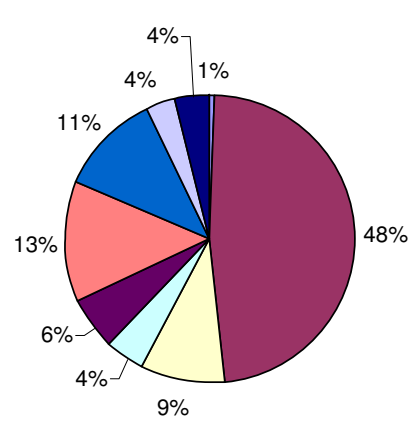

\begin{tabular}{|lll|}
\hline$\square$ Nil & $\square$ Heavy workload & $\square$ Financial \\
$\square$ Family & $\square$ Domestic responsibility & $\square$ Relationship with colleague \\
$\square$ Relationship with staff & $\square$ Other & $\square$ Missing \\
\hline
\end{tabular}

Figure I

Factors causing stress among medical students.

\section{Discussion}

This study is part of a larger project covering well-being and bullying of medical students in Pakistan. Other findings will be reported separately.

The training period for medical students is a constantly changing environment of 5 to 6 years, to ensure that graduates gain sufficient skills. Some aspects of the training have been found to have negative effects on the student's life, which manifest in the form of stress, depression and burn out.

An important finding of this survey is the prevalence of stress among medical students; about $65 \%$ of them found the training period stressful. This finding is in agreement with other studies conducted in Pakistan [8] and elsewhere [4].

An alarming result of this study is the awareness of a significant number (39.2\%) of students about smoking and alcohol (22.8\%) as coping mechanisms for stress in their colleagues. This finding lends support to previous research from Pakistan, showing that $90 \%$ of medical students perceived academic stress as being responsible for drug use among medical students [8]. Drug use among medical students is a worldwide phenomenon; for example, a survey of an American medical school showed alcohol, benzodiazepine and opiate use to be higher than agematched controls [12]. Moreover, alcohol and drug addiction represents $80 \%$ to $90 \%$ of all physician impairment cases in the US, and is a source of major concern for health authorities [13].

With regard to the main factors responsible for causing stress, the majority of the students attribute it to heavy workload $(47.4 \%)$ followed by relationship with colleagues $(13.5 \%)$ and staff $(11.9 \%)$. This finding is consistent with a BMA survey in the UK [11]. Similarly, workload such as academic studies and exams have been found to be major sources of stress among Pakistani medical students [10] though such workload varies for medical students on a yearly basis and is, usually, coupled with concerns for academic performance [4]. 
Table 3: Feedback on teaching received on substance misuse

\begin{tabular}{llll}
\hline Substances & \multicolumn{1}{l}{ Responses } & \\
\cline { 2 - 4 } & Excellent, $\mathbf{n}(\%)$ & Adequate, $\mathbf{n}$ (\%) & Poor, $\mathbf{n}(\%)$ \\
\hline Alcohol & $67(19.6)$ & $106(31.0)$ & $163(47.7)$ \\
Illegal drugs & $48(14.0)$ & $98(28.7)$ & $190(55.5)$ \\
Prescribed drugs & $59(17.3)$ & $136(39.8)$ & $141(41.0)$ \\
Over the counter drugs & $30(8.8)$ & $103(30.1)$ & $203(59.4)$ \\
Models of addiction & $33(9.6)$ & $97(28.4)$ & $206(60.2)$ \\
Management/treatment of addiction & $29(29)$ & $94(27.5)$ & $213(63.4)$ \\
Substance abuse by students/professionals & $35(10.2)$ & $110(32.2)$ & $191(55.8)$ \\
Prevention of substance abuse & $36(10.5)$ & $93(27.7)$ & $207(60.5)$
\end{tabular}

Missing, 6 each (1.8).

Almost 40\% (40.1\%) of participants reported a history of depression, while more than $50 \%$ were aware of depression among their fellow students. This is the most striking finding of our study. Similar findings have been reported in other research from Pakistan; for example, one study reported suicidal ideation in a third of Pakistani medical students [9]. In part this could be a reflection of a high prevalence of common mental disorders in Pakistan [14].

Various studies from US have identified a high frequency of depression and suicidal tendencies among medical students; in fact, suicide ranks second among the leading causes of death in medical students [15]. In a UK survey, about $14 \%$ of medical students reported depression while $53 \%$ were found aware of depression amongst their colleagues.

The medical students in this survey reported poor teaching on substance abuse. This could be explained by the fact that psychiatry is not taught as a major subject at undergraduate level in Pakistan except in a few medical colleges. As such it is understandable that students will be less likely to know a great deal about substance abuse problems.

Female medical students and government-run institutions have been found to be negatively associated with health and well-being of medical students. This finding is consistent with studies conducted previously in Pakistan [10] and elsewhere [16]. Regarding government institutes, generally less institutional support is available to the students in Pakistan. Another reason could be the fact that less affluent students only gain admission into public institutions, which could make them more vulnerable to stress.

A significant association between stress and awareness of alcohol use as a coping strategy for stress is an important finding of this study. This finding necessitates the need for further research to study actual alcohol use in stressed medical students.

\section{Limitations}

This is a preliminary study concerning medical students and substance use, with obvious limitations. Direct figures were not obtained on actual patterns of substance misuse among medical students, and associations were observed. Additionally, no attempts were made to interview students for current depressive symptoms. For psychological well-being, self-report was used instead of standard scale measurements.

Our sample may also not be representative of the population; for example, only one medical college was selected from Punjab, which is the largest province of Pakistan.

Table 4: Demographic characteristics and association with well-being

\begin{tabular}{llcl}
\hline Variables & Does work at medical school affect your personal health and well-being? & No \\
\cline { 2 - 3 } & Yes & & 0.052 \\
\hline Type of college: & 43 & 10 & 0.003 \\
Private & 165 & 75 & \\
Government & 99 & 54 & 28 \\
Gender: & 113 & 28 \\
Male & Female & &
\end{tabular}

Values statistically significant at the level of $p<0.05$. 
Table 5: Demographics and alcohol use in association with stress

\begin{tabular}{|c|c|c|c|}
\hline \multirow[t]{2}{*}{ Variables } & \multicolumn{2}{|c|}{ Has your health ever been affected by stress? } & \multirow[t]{2}{*}{ p Value } \\
\hline & Yes & No & \\
\hline Type of college: & & & 0.164 \\
\hline Private & 48 & 6 & \\
\hline Government & 195 & 46 & \\
\hline Gender: & & & 0.626 \\
\hline Male & 130 & 27 & \\
\hline Female & 118 & 21 & \\
\hline Awareness of alcohol use to cope with stress: & & & 0.044 \\
\hline Yes & 70 & 8 & \\
\hline No & 201 & 51 & \\
\hline
\end{tabular}

Values statistically significant at the level of $p<0.05$

\section{Conclusion}

High levels of distress have been reported by medical students in Pakistan, and a significant proportion reported that their well-being has been affected by stress. The vast majority of medical students reported that they know of colleagues who use alcohol and smoking to cope with stress. Moreover, workload was cited by the majority of students as the source of stress.

Depression among medical students is high, as reported by the students in this survey. There is general agreement amongst medical students that the teaching of substance abuse in medical schools is over all poor.

\section{Competing interests}

The authors declare that they have no competing interests.

\section{Authors' contributions}

AWY Conceived the idea and also took part in collection and analysis of data and wrote the initial draft of the article. SA took part in data analysis and manuscript writing. ES: did literature search and reviewed the manuscript while NB collected the data and retrieved the relevant references. SI: Analyze the data, and reviewed the manuscript. MNS: Reviewed the manuscript. MZ: entered and analyzed the data.

\section{References}

I. Moffat KJ, Mc Connachie A, Ross S, Morrison JM: First year medical student stress and coping in a problem-based learning medical curriculum. Med Educ 2004, 38:482-491.

2. Givens JL, Tija J: Depressed medical students' use of mental health services and barriers to use. Acad Med 2002, 77:918-921.

3. Ball S, Bax A: Self-care in medical education: effectiveness of health habits interventions for first-year medical students. Acad Med 2002, 77:911-917.

4. Dyrbye LN, Thomas MR, Shanafelt TD: Medical student distress: causes, consequences, and proposed solutions. Mayo Clin Proc 2005, 80:1613-1622.

5. Firth-Cozens I: Interventions to improve physicians' well-being and patient care. Soc Sci Med 200I, 52:2I5-222.

6. Gutgesell M, Reeve R, Parsons B, Morse R: Exercise and alcohol consumption among medical students. Acad Med 1999, 74:750-75I.
7. Mangus R, Hawkins C, Miller M: Tobacco and alcohol use among 1996 medical school graduates. JAMA 1998, 280: I 192-I I 93.

8. Shafiq M, Shah Z, Saleem A, Siddiqi MT, Shaikh KS, Salahuddin FF, Siwani R, Naqvi H: Perceptions of Pakistani medical students about drugs and alcohol: a questionnaire-based survey. Subst Abuse Treat Prev Policy 2006, I: I I- I8.

9. Kokar S, Khan MM: Suicidal ideation in Pakistani medical students. Crisis 2005, 26:125-127.

10. Sheikh BT, Arsalan Kahloon A, Kazmi M, Khalid H, Nawaz K, A Khan $\mathrm{N}$, Khan S: Students, stress, and coping strategies: a case of Pakistani medical school. Educ Health 2004, 17:346-353.

II. British Medical Association: Medical students welfare survey report 2006. [http://www.bmahouse.org.uk/ap.nsf/Content/ welfare2005].

12. Baldwin DC, Hughes PH, Conard SE, Storr CL, Sheehan DV: Substance use among senior medical students: a survey of 23 medical schools. JAMA 1991, 265:2074-2078.

13. Aresteiguieta CA: Substance abuse, mental illness, and medical students: the role of Americans with Disabilities act. JAMA 1998, 279:80.

14. Mirza I, Jenkins R: Risk factors, prevalence, and treatment of anxiety and depressive disorders in Pakistan: a systematic review. BMJ 2004, 328:794.

15. Hays LR, Cheever T, Patel P: Medical students suicide, 19891994. Am J Psychiatry 1996, I 53:553-555.

16. Amr M, Gilany AH, El-Hawary A: Does gender predict medical students' stress in Mansoura, Egypt? Med Educ Online 2008, 13:12.
Publish with Bio Med Central and every scientist can read your work free of charge

"BioMed Central will be the most significant development for disseminating the results of biomedical research in our lifetime."

Sir Paul Nurse, Cancer Research UK

Your research papers will be:

- available free of charge to the entire biomedical community

- peer reviewed and published immediately upon acceptance

- cited in PubMed and archived on PubMed Central

- yours - you keep the copyright

Submit your manuscript here:

http://www.biomedcentral.com/info/publishing_adv.asp
BioMedcentral 